\title{
ANALYSIS OF SELECTED INDICATORS OF POVERTY \\ IN THE V4 COUNTRIES
}

DOI: http://dx.doi.org/10.18509/GBP.2015.54

UDC: 364.662/331.56(4-672EU)

\author{
RNDr. PaedDr. Ján Veselovský, PhD. \\ RNDr. Magdaléna Nemčíková, PhD. \\ RNDr. Lucia Šolcová, PhD. \\ RNDr. Hilda Kramáreková, PhD.
}

Constantine the Philosopher University in Nitra, Faculty of Natural Sciences, Department of Geography and Regional Development, Slovakia

\begin{abstract}
Progress and modernization of society does not bring only positive events and results, but also undesirable drawbacks, an example of which is the poverty. Poverty exists in every society, in terms of its economic and social reasons also in different geographical dimensions. Timeliness and relevance of this social phenomenon is also evident from other statistical surveys in EU countries. Whereas in 2013 was 122.6 million of EU population at risk of poverty or social exclusion (24.5\% of the population), the EU decided to include the fight against the poverty and social exclusion in the new programming period 2014-2020 as one of the five major objectives in the Europe 2020 Strategy. Poverty reduction is a priority of the Visegrad Group (V4) countries, which are characterized not only spatial, but also economic homogeneity. In this paper we analyse the selected indicators of poverty (e.g. from the area of unemployment, income, education, etc.) in the common geographical area of the V4 countries. In the article we used standard scientific methods, mostly mathematical and statistical methods, analysis and interpretation of statistical data, visualization of information will be applied by graphical methods and via GIS.
\end{abstract}

KEYWORDS: Poverty. Risk of Poverty. Indicators of Poverty. Visegrad Group (V4) Countries.

\section{INTRODUCTION}

The Visegrad Group (hereinafter referred to as "V4") is an informal regional alliance of the four member states of the European Union (hereinafter referred to as "EU") and the North Atlantic Treaty Organization (hereinafter referred to as "NATO") - Slovakia, Czech Republic, Hungary and Poland, which endorse the same values, have a common history, culture and geographical position.

Despite the fact that V4 presents a dynamic regional coalition of EU member states, it has to face many problems during its development, and one of them is the problem of poverty. Therefore the aim of this paper lies in the processing of level of poverty through selected indicators within the mentioned countries at the NUTS 1 and NUTS 2 level.

\section{THEORETICAL AND METHODICAL BACKGROUND}

The economic disparities among European regions were diminishing until the outburst of global financial and economic crisis in 2008. "Poorer" regions were generally approaching "richer" regions by the process of convergence. However, the crisis has 
largely influenced not only economic, but the social situations in regions, as well. The post-crisis period has increased inequalities especially in the areas that have been mostly affected by the crisis. This development has become evident also in V4 countries, what is documented by various studies, e.g. [5, 9, 10, 12]. Also the relatively separate issues of poverty nowadays belong to the frequently discussed topics. The authors deal with its manifold aspects, such as its indicators and measurement [7, 1], disparities [8], sociological [6] and medical and geographical aspects [11], etc.

It is estimated that circa 84.5 million of the total 505.67 million inhabitants of EU member states lived in poverty in 2013 (8.5 million of them were people in V4 countries). The goal of the Europe 2020 Strategy is to reduce the number of inhabitants living in poverty and social exclusion by 20 million (within V4 countries by 2.15 million).

During the processing of paper were used the regions at NUTS 2 level because of comparability of the latest information. The statistical data from 2011 and 2012 were obtained from the Eurostat database [2] and the European Union Statistics on Income and Living Conditions (hereinafter referred to as "EU SILC") - harmonized survey is conducted annually in the whole EU and is used for comparison of regional, national and international disparities especially in the field of poverty [3]. We took into account the fact that just during this term were fully reflected consequences of the crisis in the Central Europe.

We analysed 11 partial indicators (Table 1), which are used within the evaluation of poverty level. We contacted experts, who in the discussion mutually compared always just two indicators, respectively criteria and identified more significant criterion within the each pair. In the process of determination of weight of particular indicator was used mathematical Fuller method (method of pairwise criteria comparison [4]).

Table 1 Weight of selected indicators of poverty

\begin{tabular}{|l|r|}
\hline Indicator & Weight of Indicator in \% \\
\hline Unemployment rate & 14.4 \\
\hline Long-term unemployed persons & 16.2 \\
\hline Unemployment rate persons up to 24 years old & 3.7 \\
\hline Population aged 25 -64 with lower secondary education attainment & 8.3 \\
\hline Population aged 25 - 64 with tertiary education attainment & 2.0 \\
\hline Households with 5+ members & 5.5 \\
\hline Balance of primary income per inhabitant & 9.1 \\
\hline Disposable income per inhabitant & 10.9 \\
\hline Social benefits in region & 5.5 \\
\hline Social benefits per inhabitant & 6.4 \\
\hline At-risk-of-poverty rate after social transfers & 18.0 \\
\hline
\end{tabular}

Subsequently were applied methods of multi-criteria analysis [4] in order to achieve the synthetic indicator of poverty. We used two methods with different calculation principle - Ideal Point Analysis (hereinafter referred to as "IPA") and Concordance Discordance Analysis (hereinafter referred to as "CDA"). The findings were visualized via ArcGIS.

\section{SPATIAL DISPARITIES OF INDICATORS (ANALYSIS)}

Different population groups face the different risk of poverty. In accordance with the Eurostat data, the households with unemployed person are most likely poorer than other. Interconnectedness among unemployed people and a group of people at the highest risk of poverty is the result of modern society that is understood as a working society. It shows that the position in the labour market (or even exclusion from its scope) means 
one of the most significant indicators of the risk of poverty. Solving of poverty is in this case associated with the solving of unemployment, while there are essential changes. In the industrial society, there were quantitative unemployment and jobless people were a consequence of redundancy, while in the third-wave society there is a qualitative unemployment and people are without job because of the lack of education as a substantial assumption for being successful in the labour market of information society. The unemployment rate is considered to be the basic and most frequently used indicator of unemployment reflecting the proportion of registered unemployed in the total number of economically active population (in \%). Since the late Seventies there has occurred a formation and growth of the massive unemployment also in developed countries leading to poverty of whole social categories and individuals, who were not successful in the labour market [6]. A significant part of the poor in the V4 countries is associated just with the lack of working opportunities and unemployment. The average level of the unemployment rate in V4 countries reached $10.12 \%$ in 2012. Although is the mentioned number lower than the EU average $(10.6 \%)$ by $0.48 \%$, but there were large differences between particular states. The highest value was registered in Slovakia (14\%), followed by Hungary with the above-average level (10.9\%). Poland $(10.1 \%)$ and the Czech Republic (7\%) reached values below the EU average. At the NUTS 2 level was detected the highest unemployment rate in the Eastern Slovakia (19\%) that was by $8.4 \%$ more than EU average and by $8.88 \%$ higher than V4 average. Also the other regions typical for high unemployment stretched in the north-south direction of the east part of V4 (Poland - Podkarpackie 13.2\%, Hungary - Észak-Magyarország 16.6\%). On the other hand, the lowest values of unemployment were registered in the regions of capital cities (Praha 3.1\%, Bratislavský kraj 5.7\%).

The most substantial problem of unemployment is a long-term unemployment. The man, who is unemployed for a long term is in the register of Labour office more than 12 months. We analysed the proportion of registered unemployed over 12 months in the total number of unemployed (in \%). For this group of people it is a great problem to find a job and include oneself in the standard way of life. Unemployment and especially a long-term unemployment (among the all mentioned indicators) evince a bright correlation with poverty. In case of this indicator, the situation within the V4 countries is very unfavourable. It is approved by the value of long-term unemployment $(43.8 \%)$ that is by $10.5 \%$ higher than the EU average (33.3\%). The most negative level (67.3\%) in the V4 countries as well as in the whole EU was in Slovakia, what means that more than twothirds of unemployed belonged to the group of long-term unemployed people. The other V4 countries reached the similar level of long-term unemployment (Hungary 45\%, the Czech Republic 43.4\%, Poland 40.3\%). Among the NUTS 2 regions was the highest value registered in the Východné Slovensko (71.1\%), followed by Stredné Slovensko $(67.6 \%)$ and Západné Slovensko (65.9\%).

A very significant problem is the youth employment that disables to use necessary knowledge from school in the first job and thus does not create any work habits. A failure in creation of work habits at young age minimizes chances to get employed later and creates a habit for social benefits. The average level of unemployment up to 24 years (youth employment) reached $26.2 \%$ in the V4 countries in 2012, what was by $3 \%$ higher than the EU average (23.2\%). The highest number of youth unemployment was recorded in Slovakia (34\%) reflecting that every third economically active young person was unemployed. Hungary followed Slovakia with the above-average level of the indicator $(28.1 \%)$ and was followed by Poland (26.5\%) and Czech Rep (only 19.5\%). 
The unfavourable situation was mostly within the eastern NUTS 2 regions in Slovakia (Východné Slovensko - 43\%), Poland (Podkarpackie 40.8\%) and Hungary (ÉszakMagyarország 38.7\%). Contrary to that, a pleasing position was registered in the central and southern Czechia (Praha 11.9\%, Střední Čechy 13.3\% and Jihozápad 13.2\%).

Another risk group is represented by low educated people. Despite the fact that a level of education has yet reflected into the income level not so fully as in the Western Europe and intellectual work does not mean the protection against monetary poverty, so people with lower or absent education belong to one of the groups most at the risk of poverty. A low level of education is typical for population living in the regions with high unemployment rate (a significant link between education and unemployment). The problematic issues of inhabitants' education have not often only historical roots, but they also suffer from current social and economic problems (increased costs of travel, accommodation, meals, study literature, etc.). Especially unfavourable is the situation in the regions with high percentage of Roma minority with very low level of education. Higher education gives better chances in the labour market and it excludes those with lower education. Not all unemployed are able to improve their knowledge and find own emplacement in the labour market and are labelled as unemployable. Just these persons form with a high probability the potential group of the poor [7]. Just significant disparities of education are the cause of noticeable economic backwardness and poverty in various regions. Within the V4 Group, there are $12.1 \%$ low educated people on average; the highest level was recorded in Hungary (18.2\%), what is considerably higher than the V4 average. The second highest level was registered in Poland and it was by $1 \%$ lower than the V4 average. Low as well as positive numbers in terms of occurrence of poverty were distinguished in Slovakia (8.7\%) and Czech Republic (7.7\%). Within the regions at NUTS 2 level was very unfavourable situation in Hungary (Észak-Alföld 24.9\% and Észak-Magyarország 22.4\%).

An important factor in the process of detection of poverty is completed university education (tertiary education - ISCED 5 and 6). The higher education makes higher chances to get a job and achieve higher income. This type of education reduces the level of risk of poverty. Therefore, it is one of the main goals of the Europe 2020 Strategy to reach at least $40 \%$ of people at age from 30 to 34 yrs. with completed university education. In 2011, on average $26.8 \%$ of population aged $25-64$ yrs. in EU reached university education. Contrary to that, the average value in the each V4 country was below the mentioned average (Poland (23.3\%), Hungary (21.1\%), Slovakia (18.6\%), Czech Republic (18.2\%)). Within the NUTS 2 regions was registered share above average in Bratislavský kraj (37.9\%), Praha (37.5\%), Mazowieckie (31.9\%) and KözépMagyarország (31.4\%). The lowest proportion of university educated people aged $25-$ 64 yrs. was typical for Czechia (Severozápad (9.9\%), Severovýchod (14.8\%) and Jihozápad (15.1\%)).

The carrier of poverty can also be households with 5 or more members, especially with lower incomes. An elimination of bringing an income into a family by children (except family allowances) and their consequent calculation to particular family members highlights the relation that the more children are in family (more family members), the lower amount is for the each member of family and the standard of living is on the decrease (more children $=$ lower amount of money $=$ higher risk of poverty). Within the model of small family may be the third child a critical point, whose birth can entail a disproportional growth of costs and consequent decrease of the standard of living of family [7]. The average net monthly income per person diminishes within households 
with one child approximately at the level of $75 \%$, within families with two children at $65 \%$ and in families with more than two children at $50 \%$ of income average of childless households. Various forms of material deprivation are being felt mostly in families with several children, which can oscillate at the level of subsistence although the economic activity of both parents. The highest proportion of families with several children was registered in Slovakia (14.3\%), followed by Poland (13.9\%), Hungary (10.3\%) and Czech Republic (only 7.5\%). Within the NUTS 2 regions was the highest proportion of families with several children in the south-eastern territories of Poland - Podkarpackie (22.8\%), Malopolskie (19.2\%), Swietokrzyskie (17.1\%), which are further stretched into NUTS 2 regions in Slovakia (Východné Slovensko (19.8\%) and Stredné Slovensko $(15 \%)$. We can assume that this fact is not only associated with the higher proportion of religious population, but higher percentage of Roma minority in these regions, as well.

For purposes of comparison of purchasing power of inhabitants in particular NUTS 2 regions is presented a disposable income in purchasing power consumption standard (hereinafter referred to as "PPCS"). A comparison between primary income and disposable income shows the levelling influence that state intervention generally plays. In 2011 the highest disposable income per capita across the EU was registered in Luxembourg (23,800 PPCS), followed by Austria (19,800 PPCS) and Germany (19,500 PPCS). The V4 countries were presented by these values: Slovakia $\left(10,500\right.$ PPCS $-17^{\text {th }}$ of the EU27), Czech Republic (10,200 PPCS), Poland (9,800 PPCS) and Hungary (8,600 PPCS). Within the regional scope was reached the above-average number by Bratislavský kraj (16,000 PPCS). The second highest value of disposable income was typical for Praha $(13,500$ PPCS $)$ and the third position achieved the region of Polish capital Mazowieckie (13,100 PPCS). The lowest values of disposable incomes were registered in two Hungarian regions (Észak-Alföld 7,200 PPCS and Észak-Magyarország 7,300 PPCS) and one Polish territory (Podkarpackie 7,200 PPCS).

Another indicator that helps not only identify regional disparities of poverty, but also diminish the level of poverty is represented by social benefits. Social benefits paid by governments in 2011 reached $16.1 \%$ proportion of GDP in the whole EU. The biggest share within the V4 countries was registered in Hungary (15.4\% of GDP - 16.2 million Euro), followed by Poland (13.9\% of GDP - 52.3 million Euro), Slovakia (13.8\% of GDP - 9.7 million Euro) and Czech Republic (13.1\% of GDP - 22.5 million Euro). The highest amounts of social benefits received the two most populous NUTS 2 regions of Poland (Slaskie 8.2 million Euro and Mazowieckie 7.3 million Euro). On the other hand, the lowest amount of money in form of social benefits received inhabitants of Bratislavský kraj (1.1 million Euro), which is also the least populous territory within monitored NUTS 2 regions. Through the recalculation of social benefits per capita in the V4 countries was registered the best result in Czech Republic that reached a national average above 2,000 Euro (2,140 Euro) as the only one of the all 4 countries, while all of its NUTS 2 regions recorded values above this threshold (max. Praha (2,215 Euro), min. Jihozápad (2,020 Euro)). The second one was Slovakia (1,818 Euro), followed by Hungary (1,623 Euro) and the last one was Poland (1,357 Euro). In case of Poland, just residents of Slaskie NUTS 2 region received in 2011 social benefits much higher than the national average (1,784 Euro). The inhabitants of 12 out of the total 16 NUTS 2 regions received social benefits lower than the Polish average, while the lowest value was registered in Podlaskie NUTS 2 region (1,138 Euro). 
The last input indicator into synthetic parameter was at-risk-of-poverty rate after social transfers. This indicator was characterized by the strongest weight, because it inputs as the one of three partial indicators (with material deprivation rate and low work intensity rate) to the Aggregate indicator of poverty or social exclusion.

The lowest value of the at-risk-of-poverty rate within the V4 countries and also the whole EU was registered in 2011 in Czech Republic (9.8\%), only Iceland reached the lower number $(9.2 \%)$ from European countries. The Czech Republic belongs to the countries with low at-risk-of-poverty rate in Europe in the long-term period. Below the EU27 average $(16.9 \%)$ was also Slovakia $(13 \%)$ and Hungary $(13.8 \%)$, but Poland reached the above-average value (17.7\%). The all four V4 countries reached annual growth of the selected indicator from 0.1 (Poland) to 1.5 (Hungary) percentage point. Within the NUTS 2 regions (Map 1) were registered the lowest values of the at-risk-of-poverty rate in the three territories in Czech Republic - Praha (4.6\%), Střední Čechy (6.1\%), Jihozápad $(7.3 \%)$ - and the one region in Slovakia (Bratislavský kraj - 7.2\%). Conversely, the highest values of the at-risk-of-poverty rate showed four NUTS 2 regions in Poland Lubelskie (31.3\%), Swietokrzyskie (25.5\%), Lubuskie (25.1\%) and Podkarpackie $(21.3 \%)$.

\section{REGIONS OF POVERTY IN V4 COUNTRIES (SYNTHESIS)}



The synthetic indicator of the level of poverty created by the CDA method is visualized on the Map 2. The highest level of poverty was detected in 10 NUTS 2 regions (6 Polish, 3 Hungarian, 1 Slovak), while a continuous stretch of poverty was formed by seven regions located at the eastern and south-eastern border. The poorest territories were 2 Polish NUTS 2 regions - Swietokrzyskie a Lubelskie. The six out of total 35 NUTS 2 regions reached the high level of poverty (3 Polish, 1 Slovak, 1 Hungarian, 1 Czech). On the other hand, the lowest intensity of poverty was registered in 3 Czech regions (Praha, Střední Čechy and Jihozápad) and 1 Slovak territory (Bratislavský kraj).Map 1 At-risk-ofpoverty rate after social transfers of V4 countries by NUTS 2 in 2011

The synthetic indicator of poverty created by the IPA method (Map 3) shows; in comparison with the above mentioned

model; identically earmarked regions with very low and low level of poverty. There are seven territories especially at risk of poverty (3 Polish regions - Lubelskie, Swietokrzyskie, Podkarpackie; 2 Slovak - Východné Slovensko, Stredné Slovensko; 2 Hungarian - Észak-Magyarország and Észak-Alföld). Východné Slovensko was the poorest region of all. There were identified 19 regions with very high or high level of poverty through application of the selected method (using the CDA method were identified just 16 regions). 
Map 2 Regions of poverty in the V4 Countries by the CDA method

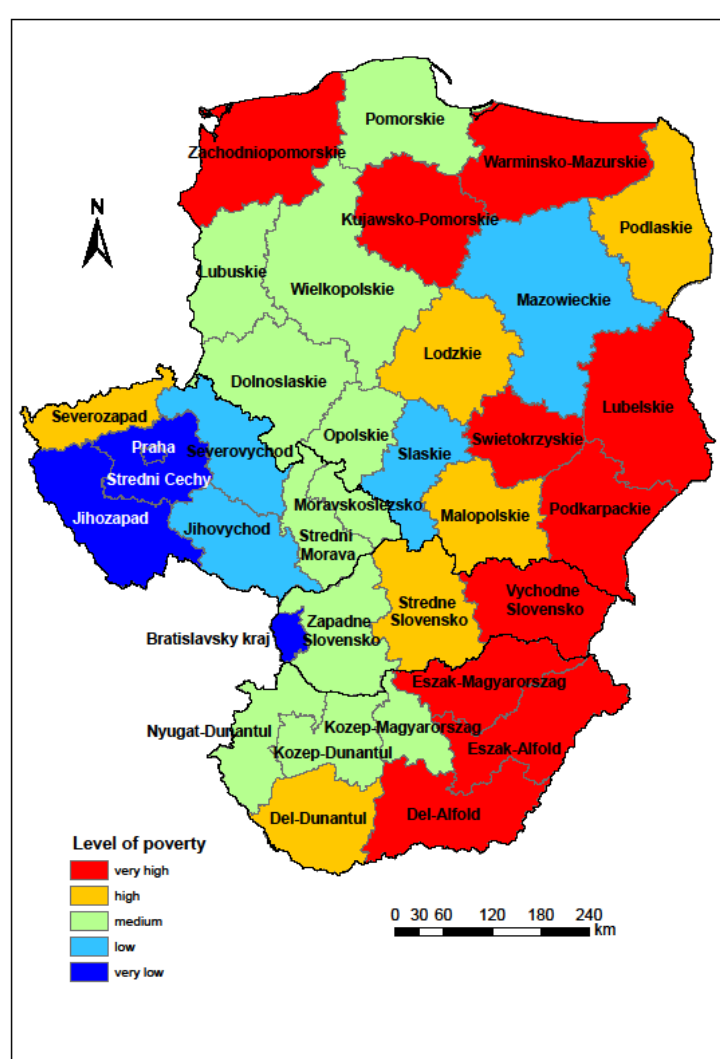

Map 3 Regions of poverty in the V4 countries by the IPA method

\section{CONCLUSION}

The comparison of the Map $1-3$ found out that the correlation of three used methods is quite high (80\%). The largest disparities were identified in three NUTS 2 regions in Slovakia (except Bratislavský kraj), the same number of NUTS 2 units in Hungary (DélDunántul, Észak-Magyarország, Észak-Alföld) and in Poland, too (Zachiodniopomorskie, Kujawsko-Pomorskie, Warminsko-Mazurskie). These differences will be the objectives of future studies. The fastest regional economic growth in proportion to the EU average was recorded from 2008 to 2011 within the territories of capital cities of Slovakia (Bratislavský kraj) and Poland (Mazowieckie). A manifold expansion of poverty at the NUTS 2 level is the reflexion of various factors, which reflect in different areas with particular development and landscape structure in different ways. 


\section{REFERENCES}

[1] Betti, G. \& Gagliardi, F. \& Lemmi, A. \&Verma, V. National indicators of poverty and deprivation in Europe: methodology and applications, Cambridge Journal of Regions, Economy \& Society, UK, vol. 5 issue 1, pp. 129, 2012

[2] Eurostat, http://ec.europa.eu/eurostat/web/main/home.

[3] EU SILC http://ec.europa.eu/eurostat/web/microdata/european_union_statistics _on_income_and_living_conditions

[4] Korviny, P. Teoretické základy vícekriteriálního rozhodování, Czech Republic, 2015, 31 p. http://korviny.cz/mca7/soubory/teorie_mca.pdf

[5] Krogmann, A. \& Pulpitlová, M. Humánno-geografický výskum pohraničného územia okresu Levice a pril'ahlej župy Peštianskej a Novohradskej, Zborník z III. vedeckej konferencie doktorandov konanej pod záštitou dekana FPV s medzinárodnou účast'ou, Slovak Republic, 2002, pp. 333-338.

[6] Mareš, P. Sociologie nerovnosti a chudoby, Czech Republic, 248 p., 1999

[7] Michálek, A. Meranie chudoby v regiónoch (okresoch Slovenska), Sociológia Slovak Sociological Review, Slovak Republic, vol. 36, issue 1, pp. 7-30, 2004.

[8] Michálek, A. \& Veselovská, Z. Vývoj regionálnych disparít z aspektu rizika chudoby na Slovensku po roku 2001, GEOGRAPHIA SLOVACA, Slovak Republic, vol. 28, pp. 153-171, 2014.

[9] Némethová, J. Agriculture of the Danubian euroregions of the Slovak-Hungarian borderland, Proceedings of the international colloquy - State border reflection by border region population of V4 states, Slovak Republic, 2002, pp. 231-238.

[10] Repaská, G. \& Dubcová, A. Motivational factors of migration flows and their impact on residential identity of residents in suburban zone of the Nitra, Geography and Geoinformatics: Challenge for Practise and Education : Proceedings of 19th International Conference, Czech Republic, 2012, pp. 111-124.

[11] Vilinová, K. Indikátory zdravotného stavu obyvatel'stva $\mathrm{z}$ aspektu trvalo udržatel'ného rozvoja. Geografické štúdie, Slovak Republic, vol. 16, pp. 63-74, 2012

[12] Záhoráková, D. Preconditions of regional development of the Danubian euroregions of the Slovak-Hungarian borderland, Proceedings of the international colloquy - State border reflection by border region population of V4 states, Slovak Republic, 2002, pp. 265-269. 